\title{
The Role of Synbiotic in Cobb-strain Broiler Performance Challenged with Campylobacter jejuni as a Substitute for Antibiotic Growth Promotor (AGP)
}

\author{
A E T H Wahyuni ${ }^{1, *}$ T E M Nahak ${ }^{2}$, M C C Malelak ${ }^{2}$, V C Prakasita ${ }^{3}$, and S L \\ Adrenalin ${ }^{4}$ \\ ${ }^{1}$ Department of Microbiology, Faculty of Veterinary Medicine, Universitas Gadjah Mada, Yogyakarta 55281, \\ Indonesia \\ ${ }^{2}$ Veterinary Science Study Program, Faculty of Veterinary Medicine, Universitas Gadjah Mada, Jl. Fauna No. 2, \\ Sleman, Yogyakarta, 55281, Indonesia \\ ${ }^{3}$ Department of Biology, Faculty of Biotechnology, Duta Wacana Christian Univercity, Jl. Dr. Wahidin Sudirohusodo \\ No.5-25, Kotabaru, Gondokusumanan, Yogyakarta, 55224, Indonesia \\ ${ }^{4}$ Department of Microbiology, Faculty of Veterinary Medicine, Universitas Brawijaya, Malang 65151, Indonesia \\ *Corresponding author.Email:wahyuni_aeth@mail.ugm.ac.id
}

\begin{abstract}
One of the feed additives that have long been used is Antibiotic Growth Promoter (AGP). But nowadays, the use of AGP as a growth promoter has been banned because it has negative impacts such as antimicrobial resistance. Campylobacter jejuni is a pathogenic bacterium that often infects birds, especially broilers. This research aims to investigate the role of synbiotic composed of a prebiotic, and Saccharomyces sp. and Lactobacillus sp. as probiotics (commercial products) in performance of broilers challenged with C. jejuni as a substitute for AGP. Twenty-one Day Old Chicks (DOC) of Cobb-strain broilers were divided into three groups, each consisting of 7 chicks. Group I was given basal diets, group II was given basal diets and AGP (with $250 \mathrm{~g} /$ ton of enramycin), and group III was given basal diets and synbiotic (100 gram $/ 100 \mathrm{~kg})$. C. jejuni challenge test was carried out at the $3^{\text {rd }}$ week. The results suggested that at week 4, group III showed more and significantly different body weight from that of group I, but it did not differ significantly from that of group II. Similarly, at week 4 the weight gain of group III was higher and significantly different compared to that of group I, but did not differ significantly from that of group II. Also, the carcass percentage at week 5 did not differ significantly among the groups, but group III had a higher percentage of carcasses than groups I and II. The addition of synbiotic can replace AGP as a feed additive because it can improve the performance of broilers challenged by $C$. jejuni.
\end{abstract}

Keywords: Synbiotic, AGP, Campylobacter jejuni, Broiler, Performance.

\section{INTRODUCTION}

Feed is a factor that requires the highest cost, which is around $60-70 \%$ of the total production costs. Production costs can be reduced with feed efficiency. High feed efficiency can be achieved if the digestive tract of livestock is in optimal condition for digesting and absorbing nutrients [1]. Broiler farms are generally susceptible to diseases caused by viruses, bacteria, parasites, fungi, the environment, and lack of nutrition [2]. The pathogenic microorganism that is commonly found is Campylobacter jejuni. Antibiotic resistance causes a very serious disease in humans, i.e. failure of treatment for gastrointestinal infections caused by Campylobacter sp. and Salmonella sp. [3]. Consumer awareness and restrictions on the use of antibiotic growth promoters in the poultry industry raise several alternative feed additives that can be used to replace Antibiotic Growth Promoters (AGP). One of the most widely used feed additives is synbiotic [4]. Saccharomyces sp. and Lactobacillus sp. as probiotics that function against enteropathogenic agents [5]. Prebiotics function to support the growth of probiotics so that normal microflora is maintained and cooperation between prebiotics and probiotics can inhibit the growth of enteropathogenic agents [6]. 


\section{MATERIAL AND METHODS}

This research was approved by the Research Ethics Commission of the Faculty of Veterinary Medicine, UGM (0038/EC-FKH /Int/2018).

\subsection{Experimental Design}

Twenty-one DOCs of Cobb-strain broilers were divided randomly into 3 groups, each group consisted of 7 chicks. Group I was the control group and was given basal feed, group II was given a mixture of basal feed and AGP (enramycin) at a dose of $250 \mathrm{~g} / \mathrm{ton}$, and group III was given a mixture of basal feed and synbiotic (commercial products containing Saccharomyces sp. and Lactobacillus sp. as probiotic and prebiotic) at a dose of $1 \mathrm{~kg} / \mathrm{ton}$. The basal feed used was AGP-free basal feed. The nutritional content of the basal feed can be seen in Table 1.

All chicks were vaccinated on day 1 with ND + IB live vaccine (intraocular), on day 14 with IBD live vaccine (oral), and on day 18 with booster vaccine, i.e. ND killed vaccine (intramuscular). The room temperature was maintained at $35^{\circ} \mathrm{C}$ for the first 3 days, and then gradually reduced by $3^{\circ} \mathrm{C}$ a week until it reached $24^{\circ} \mathrm{C}$. All chicks had ad libitum access to feed and water throughout the experiment.

\subsection{Bacteria Reactivation and Challenge Test}

C. jejuni isolates were obtained from the Center for Veterinary Research (BALITVET) with isolate code 2910. The isolate was then reactivated by having it infect 21-day old broilers orally with a concentration of $1 \times 10^{9}$ $\mathrm{CFU} / \mathrm{ml}$ as suggested by Naseri et al. [7]. Chicks showing clinical signs at 7-14 dpc (days post-challenge) were necropsed for bacterial isolation from caecal contents. Bacterial isolation was carried out on blood agar plates and incubated at $42^{\circ} \mathrm{C}$ for 24 hours. Bacteria with round and non-hemolytic gray colonies were taken and underwent gram staining. Then, biochemical tests were administered to spiral, gram-negative bacteria. The isolated bacteria were then used as a challenge test.

The challenge of $C$. jejuni was carried out at the $3^{\text {rd }}$ week. C. jejuni isolates from reactivation were then cultured in Brain Heart Infusion (BHI) media and incubated at $42^{\circ} \mathrm{C}$ for 24 hours. The suspension was made according to the test concentration challenge using McFarland standard with a concentration of $1 \times 10^{9}$ $\mathrm{CFU} / \mathrm{ml}$ via the oral route [7].
Table 1. The nutritional content of the basal feed

\begin{tabular}{lccc}
\hline $\begin{array}{l}\text { Nutritional } \\
\text { Content }\end{array}$ & \multicolumn{3}{c}{ Feeding Phase } \\
\cline { 2 - 4 } & $\begin{array}{l}\text { Pre- } \\
\text { starter }\end{array}$ & Starter & Finisher \\
\hline $\begin{array}{l}\text { Water content } \\
\text { (\%) Max }\end{array}$ & 13 & 13 & 13 \\
Protein (\%) & $23.0-25.0$ & $22.0-24.0$ & $20.0-23.0$ \\
Fat (\%) Min & 4 & 4 & 5 \\
Ash (\%) Max & 7 & 7 & 8 \\
Crude fibre & 5 & 5 & 5 \\
(\%) Max & & & \\
Ca (\%) Min & 0.9 & 0.9 & 0.9 \\
P (\%) Min & 0.6 & 0.6 & 0.6 \\
Lysin (\%) Min & 1.32 & 1.19 & 1.05 \\
Methionine & 0.50 & 0.48 & 0.43 \\
$(\%)$ Min & & & \\
Methionine + & 0.98 & 0.89 & 0.82 \\
cysteine (\%) & & & \\
Min & & & 0.19 \\
Tryptophan & 0.20 & 0.19 & 0.71 \\
$(\%)$ Min & & & \\
Threonine (\%) & 0.86 & 0.78 & \\
Min & & & \\
\hline
\end{tabular}

\subsection{Performance Parameters}

Body weight (BW) and body weight gain (BWG) data were obtained by measuring the weight every week from weeks 1 to 5. Chicks' weight was measured in the morning prior to food and water administration. Five chickens were taken randomly from each group at week 5 and then slaughtered to calculate the carcass percentage $(\mathrm{CP})$.

\subsection{Data Analysis}

All data obtained were analyzed using the OneWay ANOVA test with a statistical program (SPSS 24). If significant differences were found, the test would be continued with the Tukey post hoc test. The significant level at $\mathrm{P}<0.05$ was used. The data were presented in the form of mean \pm standard of error (Mean \pm SE).

\section{RESULT AND DISCUSSION}

There were no significant differences in BW $(\mathrm{P}>0.05)$ from weeks 1 to 3 among the groups. Similar results were obtained at week 5 . At week 4 , BW of group III was higher than those of groups I and II. During the week, there were significant differences $(\mathrm{P}<0.05)$ between groups III and I. There was no significant difference in $\mathrm{BWG}(\mathrm{P}>0.05)$ starting from weeks 1 to 3 . Significant differences were obtained at week 4, with group III having higher and significantly different $\mathrm{BW}(\mathrm{P}<0.05)$ compared to that of group I. In that week, group III also had higher BWG compared to group II but it did not differ, significantly $(\mathrm{P}>0.05)$ (Table 2). There was no significant difference $(\mathrm{P}>0.05)$ in the carcass percentage among the groups. Group III had the highest carcass percentage, followed by group II and group I, respectively. Group III showed a higher 
Table 2. Bodyweight (BW) and body weight gain (BWG) from group I, II and III

\begin{tabular}{|c|c|c|c|c|c|}
\hline \multirow[t]{2}{*}{ Group } & \multicolumn{5}{|l|}{$\mathrm{BW}(\mathrm{g}) \pm \mathrm{SE}$} \\
\hline & Week 1 & Week 2 & Week 3 & $\begin{array}{l}\text { Week } 4 \\
(7 \mathrm{dpc})\end{array}$ & $\begin{array}{l}\text { Week } 5 \\
(14 \mathrm{dpc})\end{array}$ \\
\hline I & $139.83 \pm 7.29^{\mathrm{a}}$ & $439.83 \pm 21.25^{\mathrm{a}}$ & $889.33 \pm 54.63^{\mathrm{a}}$ & $1065.83 \pm 62.15^{\mathrm{a}}$ & $\underset{\mathrm{a}}{1651.33 \pm 123.65}$ \\
\hline II & $168.33 \pm 11.24^{\mathrm{a}}$ & $508.00 \pm 23.75^{\mathrm{a}}$ & $1001.50 \pm 23.64^{\mathrm{a}}$ & $1228.16 \pm 26.83^{a b}$ & $1825.00 \pm 42.53^{\mathrm{a}}$ \\
\hline III & $148.67 \pm 7.01^{\mathrm{a}}$ & $447.00 \pm 28.79^{\mathrm{a}}$ & $944.33 \pm 38.95^{\mathrm{a}}$ & $1268.80 \pm 52.91^{\mathrm{b}}$ & $1919.50 \pm 83.76^{\mathrm{a}}$ \\
\hline $\begin{array}{l}\text { Significant } \\
\text { Level } \\
(\mathrm{P}<0,05)\end{array}$ & Ns & ns & ns & $*$ & ns \\
\hline \multirow[t]{2}{*}{ Group } & \multicolumn{5}{|l|}{$\mathrm{BWG}(\mathrm{g}) \pm \mathrm{SE}$} \\
\hline & Week 1 & Week 2 & Week 3 & $\begin{array}{l}\text { Week } 4 \\
(7 \mathrm{dpc})\end{array}$ & $\begin{array}{l}\text { Week } 5 \\
(14 \mathrm{dpc})\end{array}$ \\
\hline $\mathrm{I}$ & $88.83 \pm 7.34^{\mathrm{a}}$ & $300.00 \pm 17.03^{\mathrm{a}}$ & $449.50 \pm 33.88^{a}$ & $176.50 \pm 16.65^{\mathrm{a}}$ & $618.67 \pm 33.96^{\mathrm{a}}$ \\
\hline II & $110.33 \pm 10.67^{a}$ & $339.66 \pm 12.81^{\mathrm{a}}$ & $493.50 \pm 7.42^{\mathrm{a}}$ & $226.67 \pm 32.95^{\mathrm{ab}}$ & $615.80 \pm 42.37^{\mathrm{a}}$ \\
\hline III & $91.33 \pm 5.61^{\mathrm{a}}$ & $298.33 \pm 23.98^{\mathrm{a}}$ & $497.33 \pm 30.21^{\mathrm{a}}$ & $306.20 \pm 42.70^{b}$ & $663.00 \pm 21.12^{\mathrm{a}}$ \\
\hline $\begin{array}{l}\text { Significant } \\
\text { Level } \\
(\mathrm{P}<0,05)\end{array}$ & ns & ns & ns & $*$ & Ns \\
\hline
\end{tabular}
(Table 3)

percentage of carcass value than the other groups

Lactobacillus spp. is one of the probiotics used widely in the poultry industry. Oral administration of probiotics can increase the immune response [8]. This accords with the research conducted by Brisbin et al. [9] which reveals that $\mathrm{L}$. acidophilus can increase the level of antibodies to the keyhole limpet hemocyanin (KLH) which produces systemic antibodies and cellular immune response ( $\mathrm{T}$ helper-1 cell). They have the ability to produce bacteriocin (lactase B), making these bacteria can minimize pathogens [10]. They can effectively inhibit growth and colonization in the intestinal pathogen Campylobacter jejuni [11].

Saccharomyces spp. is a natural source of protein, minerals, and vitamin B complexes containing 1,3-1,6 D-glucan and mannan-oligosaccharide, which functions as a natural growth promoter that is important for poultry production [12]. Fungi are one of the probiotics that function as a good immunostimulant and therefore can be used to increase productivity and bioregulator of intestinal microbes [13]. The mannan-oligosaccharide content on cell walls increases intestinal villi length, especially during the first seven days of chicken life [14]. The beta D-glucan component is useful for the effectiveness and intensity of the body's defense system through specific leukocyte activity such as macrophages and Natural Killer (NK) cells. Beta D-glucan will bind to the surface of macrophage cells and NK cells, and function as a trigger for the activation process of macrophages [15].

So far, there were few reported studies evaluating the effect of the combination of Lactobacillus spp. and Saccharomyces spp. on the growth performance of broiler. The results have shown that $\mathrm{BW}$ and $\mathrm{BWG}$ improved among broilers that received Lactobacillus spp. and Saccharomyces spp. as feed additives compared to those given basal diets. This research shows that the addition of a combination of probiotics significantly increased $(\mathrm{P}<0,05) \quad \mathrm{BW}$ and $\mathrm{BWG}$ of broilers during 28 days of age. Similar results were obtained by Vantsawa et al. [16], who reveal that supplementation of Lactobacillus spp. for 6 weeks also increases the performance of broilers. In contrast, Seranggi et al. [17] observed that the diets containing prebiotics, probiotics, and synbiotic did not show any significant effect on $\mathrm{BW}, \mathrm{BWG}$, and the percentage of carcass between the control and experimental groups.

Table 3. Carcas percentage (CP) from group I, II and III

\begin{tabular}{cl}
\hline Group & \multicolumn{1}{c}{ CP $(\%)$} \\
\hline I & $60.68 \pm 8.28^{\mathrm{a}}$ \\
II & $71.87 \pm 2.75^{\mathrm{a}}$ \\
III & $73.80 \pm 0.64^{\mathrm{a}}$ \\
Significant Level $(\mathrm{P}<0.05)$ & $\mathrm{ns}$
\end{tabular}

\footnotetext{
a The same superscripts in each row show no significant differences $(\mathrm{P}>0.05)$ between groups

${ }^{\mathrm{ns}}$ non significant differences
}

The highest percentage of carcass value was obtained from group III, followed by group II and group I, respectively. There was no significant difference $(\mathrm{P}>0,05)$ observed in the carcass percentage among the groups. The present findings from the report of Seranggi et al. [17] and Chumpawadee et al. [18] indicate that prebiotics, probiotics, and symbiotic have no significant $(\mathrm{P}>0,05)$ positive effect on the carcass percentage of broilers. 


\section{CONCLUSION}

The addition of synbiotic can replace AGP as a feed additive because it can improve the performance of broilers challenged by $C$. jejuni.

\section{REFERENCES}

[1] Anonim 2002 Enzim Komponen Penting Dalam Pakan Bebas Antibiotik. www.agriteknotripod.com (15 Juli 2019)

[2] Tamalludin F 2012 Ayam Broiler, 22 Hari Panen Lebih Untung (Jakarta. Penebar Swadaya) p.10

[3] WHO 1997 The Medical Impact of the Use of Antimicrobials in Food Animals: Report and Proceedings of a WHO Meeting 13-17 October Berlin Geneva

[4] Pedroso AA, Hurley-Bacon AL, Zedek AS, Kwan TW, Jordan AP, Avellaneda G, Hofacre CL, Oakley BB, Collett SR, Maurer JJ, and Lee MD 2013 Can Probiotics Improve the Environmental Microbiome and Resistome of Commercial Poultry Production? Int. J. Environ. Res. Public Health 10 4534-59

[5] Filho-Lima JVM, Vieira EC, and Nicoli JR 2001 Antagonistic Effect of Lactobacillus acidophilus, Saccharomyces boulardii and Escherichia coli Combinations Against Experimental Infections with Shigella flexneri and Salmonella enteritidis subsp. Typhimurium in Gnotobiotic Mice J. Appl. Microb. 88 365-370

[6] Depeint F, Tzortzis G, Vulevic J, Anson K and Gibson GR 2008 Prebiotic Evaluation of a Novel Galacto Oligosaccharide Mixture Produced by the Enzymatic Activity of Bifidobacterium bifidum NCIMB 41171, in Healthy Humans: A Randomized, Doubleblind, Crossover, Placebo-controlled Intervention Study Am. J. Clin. Nutr. 87 785791

[7] Naseri KG, Rahimi S and Khaki P 2012. Comparison of the Effects of Probiotic, Organic Acid and Medicinal Plant on Campylobacter jejuni Challenged Broiler Chickens J. Agr. Sci. Tech. 14 1485-1496

[8] Youssef GA, Ezzeldeen NA, Mostafa AM and Sherif NA 2011 Effects of Isolated Lactobacillus acidophilus as a Probiotic on Chicken Vaccinated and Infected with Salmonella typhimurium. Globsl. Vet. 7 449455

[9] Brisbin JT, Gong J, Orouji S, Esufali J, Mallick AI, Parvizi P, Shewen PE and Sharif S 2011 Oral Treatment of Chickens with Lactobacillus Influence Elicitation of Immune Responses. Clinical and Vaccine Immunology 18 1447-1455.
[10] Sanders ME and Klaenhammer TR 2001 Invited Review: The Scientific Basis of Lactobacillus acidophilus NCFM Functionality as a Probiotic Journal of Dairy Science 84 319-331

[11] Wang G, Zhao Y, Tian F, Jin X, Chen H, Liu X, Zhang Q, Zhao J, Chen Y, Zhang $\mathrm{H}$ and Chen W 2014 Screening of Adhesive Lactobacilli with Antagonistic Activity against Campylobacter jejuni Food Control 44 49-57

[12] Davis GV and Erhart AB 1976. Effect of Monensin and Urea in Finishing Steer Rations. J. Anim. Sci. 43 1-7

[13] Ahmad RZ 2005 Pemanfaatan Cendawan Untuk Meningkatkan Produktivitas dan Kesehatan Hewan. Bogor. Balai Besar Penelitian Veteriner

[14] Santin E, Maiorka A, Macari M, Crecco M, Sanchezi JC, Okada TM, Myasaka AM 2001 Performance and Intestinal Mucosa Development in Broiler Chickens Fed Ration Containing Saccharomyces cerevisiae Cell Wall J. Appl. Poult. Res. 10 236-244

[15] Life Source Basic. 2002. WGP. Beta-glucan. www.Life Source Basic.com/beta glucan.htm. (27 April 2019).

[16] Vantsawa PA, Umar T and Bulus T 2017 Effects of Probiotic Lactobacillus acidophilus on Performance of Broiler Chickens Direct Research Journal of Agriculture and Food Sciences. 5 302-306

[17] Sarangi NR, Babu LK, Kumar A, Pradhan CR, Pati PK and Mishra JP 2016 Effect of Dietary Supplementation of Prebiotic, Probiotic, and Synbiotic on Growth Performance and Carcass Characteristics of Broiler Chickens Vet. World 9 313-319

[18] Chumpawadee S, Chinrasri O, Somchan T, Ngamluan S and Soychuta S 2008 Effect of Dietary Inclusion of Cassava Yeast as Probiotic Source on Growth Performance, Small Intestine (Ileum) Morphology and Carcass Characteristic in Broilers Int. J. Poult. Sci. 7 246-250 